\title{
Attributes of Farmers in Palakkad District of Kerala in Context of Utilisation of Information and Communication Technology
}

\author{
Pooja Das*, N. K. Khare and Seema Naberia \\ Department of Extension Education, JNKVV, Jabalpur, India \\ *Corresponding author
}

\begin{abstract}
A B S T R A C T
Information and communication technology has become an inevitable part in one's life and so in the field of agriculture. So a study was conducted to know in detail the attributes of farmers and analyse how it influences the use of ICT tools. The study was performed in Palakkad district, Kerala with 120 respondents. The study showed that the majority of the farmers were middle aged ( 36 to 56 years). More than fifty per cent farmers had education up to high school level and had medium farming experiences. Maximum were marginal farmers and had low annual farm income. Maximum farmers had medium cosmopoliteness and moderate mass media exposure. Four fifth of them had medium level of innovativeness and majority were having medium level of scientific orientation, medium economic motivation as well as medium risk orientation and a 90 per cent of them had moderate information seeking behaviour. Majority of the farmers were utilising ICT tools to a moderate extent only. The study therefore strongly recommends the necessity of considering the social attributes of farmers in a region as it greatly influences the utilisation of information and communication technology tools.
\end{abstract}

\section{Introduction}

The greatest revolution that this $21^{\text {st }}$ century has been witnessing is the information revolution. This revolution has created the socalled "information society". An information society is a society which makes intensive use of information and communication technologies (Menou and Taylor, 2006). Every nation is a part of this information society or network as now the world has become a global village. The speed with which the flow of information takes place in this network with the emergence of ICT is just a mouse click away.
Information and communication technologies collectively refer to the technologies, both hardware and software, that enable humans to communicate with one another.

According to UNESCO (2004), Information and communication technologies can be broadly understood as the technologies that facilitate communication, processing and transmission of communication by electronic means. Therefore the ICT tools have penetrated deeply in all the sectors including governance, management, health, education, agriculture etc. 
When India stands second in population at the global level unbeatably for the past few years, there always co-exists a threat of food insecurity. Adding to the former, the sluggish growth of agriculture hence can result in a low production and productivity. Also the ratio of extension workers to the number of farmers in our country is also not sufficient. Amidst of such serious issues the growth and acceptance of ICT can be considered a great relief. ICTs in agriculture try to embrace all such challenges and prepare our farmers to face them by providing quick information on soil health, crop production, seed production, pest and disease management, irrigation, harvesting and post- harvest technologies

The adoption and utilisation of various ICT tools are influenced by many factors. Therefore the study focuses on the profile of the farmers in Palakkad district of Kerala to critically analyse the current scenario with regards to utilisation of ICT tools.

\section{Materials and Methods}

The study was conducted in Palakkad district of Kerala, popularly known as the 'rice granary' of Kerala. The location was purposefully selected because of its great agricultural significance. Palakkad district comprises 5 taluks and 156 villages. Considering the total number of villages and number of farmers, Ottappalam taluk was selected for the study.

A total of 120 farmers were selected for the study. 10 farmers were selected randomly from each 12 villages. The list of farmers was collected from Krishi Bhavan of respective villages.

\section{Results and Discussion}

The results of the study have been shown in the below table 1 . The profiles of the farmers were studied using 12 variables including social, economic, communication and psychological variables.

The study has revealed that a little less than half ie. 49.17 per cent belonged to middle age group (36 to 56 years) and 48.33 per cent in old age ( $>56$ years) group followed by 2.50 per cent of young farmers $(<35$ years). When observed closely, it can be seen that the number of young farmers in the locality was drastically low. It is observed that more than half $(55.83 \%)$ of the farmers were formally educated up to high school and 15 respondents were educated up to middle school followed by 4.16 per cent farmer having primary education, 9.16 per cent with secondary and 8.30 per cent with diploma education. None of them, that i.e. 0 per cent are illiterates.

As Kerala being known for its highest literacy rate, the results were not much surprising and it might be due to the better physical infrastructure and educational facilities provided by the state government which is highly appreciable. It could also be the reason behind the great acceptance of ICT programmes like Akshaya Kerala, the first eliteracy programme of Kerala. Among the total respondents only 1 farmer possessed a doctoral degree and 4 of them were post graduates $(3.33 \%)$ and 5.83 per cent of them were degree holders too.

More than half of the respondents had medium level of farming experience while 29.17 per cent farmers had low level of experience and 0nly 17.50 per cent of them had higher level of farming experience that is more than 45 years.

Almost 46.67 per cent belonged to the low income category followed by the medium income category $(35.00 \%)$ and high income category $(18.33 \%)$. 
Table.1 Distribution of respondents according to their profile

\begin{tabular}{|c|c|c|c|c|}
\hline S. No. & Variables & Category & Frequency & Percentage \\
\hline \multirow[t]{3}{*}{1.} & \multirow{3}{*}{ Age } & Young ( upto 35 years) & 3 & 2.50 \\
\hline & & Middle (36-56 years) & 59 & 49.17 \\
\hline & & Old ( above 56 years) & 58 & 48.33 \\
\hline \multirow[t]{9}{*}{2.} & \multirow[t]{9}{*}{ Education } & Illiterate & 0 & 0 \\
\hline & & Primary school & 5 & 4.16 \\
\hline & & Middle school & 15 & 12.50 \\
\hline & & High school & 67 & 55.83 \\
\hline & & Higher secondary & 11 & 9.16 \\
\hline & & Diploma & 10 & 8.30 \\
\hline & & Degree & 7 & 5.83 \\
\hline & & Post graduate & 4 & 3.33 \\
\hline & & Others & 1 & 0.83 \\
\hline \multirow[t]{3}{*}{3.} & \multirow[t]{3}{*}{ Farming experience } & Low ( up to 11 years) & 35 & 29.17 \\
\hline & & Medium (12-45 years) & 64 & 53.33 \\
\hline & & High( above 45 years) & 21 & 17.50 \\
\hline \multirow[t]{3}{*}{4.} & \multirow{3}{*}{ Farm income } & Low ( up to Rs. $1,00,000$ ) & 56 & 46.67 \\
\hline & & Medium (Rs. $1,00,000$ to $2,00,000$ ) & 42 & 35.00 \\
\hline & & High (above Rs.2,00,000) & 22 & 18.33 \\
\hline \multirow[t]{3}{*}{5.} & \multirow[t]{3}{*}{ Farm size } & Marginal $<1$ ha & 75 & 62.50 \\
\hline & & Small 1-2 ha & 39 & 32.50 \\
\hline & & Large $>2$ ha & 6 & 5.00 \\
\hline \multirow[t]{3}{*}{6.} & \multirow[t]{3}{*}{ Cosmopoliteness } & Low & 4 & 3.33 \\
\hline & & Medium & 109 & 90.83 \\
\hline & & High & 7 & 5.83 \\
\hline \multirow[t]{3}{*}{7.} & \multirow{3}{*}{$\begin{array}{l}\text { Mass } \\
\text { exposure }\end{array}$} & Low & 18 & 15.00 \\
\hline & & Medium & 85 & 70.83 \\
\hline & & High & 17 & 14.17 \\
\hline \multirow[t]{3}{*}{8.} & \multirow[t]{3}{*}{ Innovativeness } & Low & 13 & 10.83 \\
\hline & & Medium & 96 & 80.00 \\
\hline & & High & 11 & 9.17 \\
\hline \multirow[t]{3}{*}{9.} & \multirow[t]{3}{*}{ Scientific orientation } & Low & 2 & 1.67 \\
\hline & & Medium & 84 & 70.00 \\
\hline & & High & 34 & 28.33 \\
\hline \multirow[t]{3}{*}{10.} & \multirow{3}{*}{$\begin{array}{l}\text { Economic } \\
\text { motivation }\end{array}$} & Low & 1 & 0.83 \\
\hline & & Medium & 88 & 73.34 \\
\hline & & High & 31 & 25.83 \\
\hline \multirow[t]{3}{*}{11.} & \multirow[t]{3}{*}{ Risk orientation } & Low & 1 & 0.83 \\
\hline & & Medium & 88 & 73.33 \\
\hline & & High & 31 & 25.83 \\
\hline \multirow[t]{3}{*}{12.} & \multirow{3}{*}{$\begin{array}{l}\text { Information seeking } \\
\text { behaviour }\end{array}$} & Low & 11 & 9.16 \\
\hline & & Medium & 108 & 90.00 \\
\hline & & High & 1 & 0.83 \\
\hline
\end{tabular}


Table.2 Distribution of respondents according to their extent of utilisation of ICT tool

\begin{tabular}{|c|c|c|}
\hline Category & Frequency & Percentage \\
\hline Low & 6 & 5.00 \\
\hline Medium & 93 & 77.50 \\
\hline High & 21 & 17.50 \\
\hline
\end{tabular}

Since Kerala has fragmented land pieces, a majority $(62.50 \%)$ of them were marginal farmers and 32.50 per cent of them were medium farmers and just 5 per cent of the farmers had above 2 hectares of land.

Largely due to the influence of social media, most of the farmers and rural extension officers of a particular village were connected via whatsapp and facebook. Therefore a vast majority of the respondents' i.e. 90.83 per cent were in the medium category of cosmopoliteness followed by 3.33 per cent and 5.83 per cent in low and high category respectively. More than 70 per cent of the farmers had medium level of mass media exposure while only 15 and 14.17 per cent of them had low and medium level of exposure respectively. Majority i.e four fifth of them were having medium level of innovativeness. Around 10.83 per cent and 9.17 per cent had low and high levels of innovativeness respectively.

Considering their scientific orientation, 70.00 per cent that is the majority was in the medium category. Only 28.33 per cent and 1.67 per cent were in the high and low category of scientific orientation. Majority (73.34\%) had moderate level of economic motivation and 25.83 per cent and 0.83 per cent farmers had high and low economic motivation respectively. 73.33 per cent farmers had medium risk orientation followed by 25.83 per cent in high category and 0.83 per cent in low category respectively. A vast majority $(90 \%)$ were in the medium category of information seeking behaviour and 9.16 per cent respondents were in the low category and only 1 person was found to have a higher level of information seeking behaviour.

In the below presented table 2, more than three fourth of the respondents $(77.50 \%)$ belonged to the medium category of ICT utilisation followed by $17.50 \%$ in high and $5.00 \%$ in low categories. Since most of them were familiar with television, newspaper, radio and mobile phones only, ICT tools like kiosks, decision support system, e-magazines etc. were still a mile away for them. Among the 120 respondents, only 6 were grouped in the low category which surely indicates a green signal for the acceptance of new innovations in the field of agriculture.

In conclusion while considering the profile of farmers, it can be seen that the majority of the farmer ICT users were in the middle age group and more than half of them were formally educated up to high school level only with medium level of farming experiences. Because of the fragmented land pieces, more than three fifth of the farmers were marginal farmers and received lower annual income. But a vast majority was proved to be belonging to the medium cosmopolite category as the credit goes to modern ICT tools like television, radio and mobile phones as well as with moderate information seeking behaviour. Around 70 per cent of them were moderately exposed to mass media, scientifically oriented, economically motivated and risk oriented too. Lastly, around four fifth of them have medium level of innovativeness. When it comes to the utilisation of various ICT tools, it could be briefed that the highest proportion 
of the farmer respondents utilised the ICT tools in a moderate level only. This study has helped to understand the strength and weakness of our farmer community and also emphasises the urgency for the capacity building of farmers with the help of rural agricultural extension workers both at private as well as public level in the field of ICT to enable themselves to find solution for their own problems for the principle of Extension service itself is "helping the people to help themselves".

\section{References}

Menou MJ and Taylor RD. 2006. A Grand Challenge: Measuring societies. The
Information Society An International Journal. 22(5): 261-267.

UNESCO. (2004). ICT in education, definition of ICT (ICT). http://www.unesco book.org / index.phd / id= 999 .

CITES FOR SUPPORTING REFERENCES https://krishikosh.egranth.ac.in/displaybitstrea $\mathrm{m}$ ?handle $=1 / 5810094967$

https://www.researchgate.net/publication/318 446383_ICT_Usage_and_Effects_amo ng_Rural_Farming_Communities https://www.researchgate.net/publication/299 626336_Use_of_ICT_as_Extension_T ool_by_The_Farmers_of_Gazipur_Dis trict_in_Bangladesh

\section{How to cite this article:}

Pooja Das, N. K. Khare and Seema Naberia. 2020. Attributes of Farmers in Palakkad District of Kerala in Context of Utilisation of Information and Communication Technology. Int.J.Curr.Microbiol.App.Sci. 9(07): 2709-2713. doi: https://doi.org/10.20546/ijcmas.2020.907.319 